\title{
JENSA BECKERTA ZACZAROWANY ŚWIAT KAPITALIZMU ${ }^{1}$
}

\section{JENS BECKERT, IMAGINED FUTURES. FICTIONAL EXPECTATIONS AND CAPITALIST DYNAMICS}

Maciej Kassner

Instytut Filozofii Uniwersytetu Mikołaja Kopernika w Toruniu

Książce Jensa Beckerta pod tytułem Imagined Futures. Fictional Expectations and Capitalist Dynamics niemal od momentu ukazania się towarzyszy opinia dzieła przełomowego, wyznaczającego nowe kierunki w myśleniu o kapitalizmie i w badaniach prowadzonych w obrębie nauk społecznych. John Campbell, pisząc dla „American Journal of Sociology”, nazwał Imagined Futures „wspaniała książka”” (Campbell 2017: 1576), Gregory Jackson w „European Journal of Sociology” sklasyfikowal ja jako „bardzo innowacyjna i doniosła pracę z zakresu teorii socjologicznej" (Jackson 2017: 460), natomiast Paul DiMaggio na łamach ,Journal of Social Theory" przekonywał, że ,książka Beckerta wnosi istotny wkład w nasze rozumienie kapitalizmu i nowoczesnych gospodarek" (Di Maggio 2018: 1). Dzieło Beckerta zostało też dostrzeżone przez prasę popularną. W „The Atlantic” ukazał się obszerny esej na jego temat (Harrington 2016), natomiast Forbes włączył Imaginged Futures w poczet ,siedemnastu książek do czytania na plaży tego lata przez kreatywnych liderów" - cokolwiek to może znaczyć (Slocum 2016). W lipcu bieżącego roku ukazała się praca zbiorowa Uncertain Futures. Imaginaries, Narratives and Calculation in the Economy pod redakcja Jensa Be-

\footnotetext{
${ }^{1}$ Niniejsza publikacja powstała w ramach projektu badawczego „Rynek i polityka. Studium filozofii politycznej Karla Polanyiego", finansowanego przez Narodowe Centrum Nauki (numer rejestracyjny wniosku: 2016/20/S/HS5/00556).
} 
cekrta i Richarda Broncka, która rozwija zarysowaną przez niemieckiego socjologa perspektywę badawczą (Beckert i Bronk 2018).

Jak się wydaje, do sukcesu Imagined Futures przyczyniły się zarówno walory merytoryczne pracy, jak i korzystna konfiguracja czynników instytucjonalnych. Jak piszą Felipe Gonzales i Marcin Serafin we wprowadzeniu do wywiadu z Jensem Beckertem, niemiecki badacz jest „kluczową postacią drugiego pokolenia socjologów gospodarczych, które wyłoniło się po odrodzeniu tej dyscypliny w latach 80. za sprawa pionierskich prac Marka Granovettera, Harrisona White'a, Vivany Zelizer, Franka Dobbina, Richarda Swedberga i Neila Filgsteina", a jego prace w znacznym stopniu przyczyniły się do ,instytucjonalizacji socjologii gospodarczej w Europie” (Gonzales, Serafin 2017: 239). Beckert pełni obecnie funkcję dyrektora w Instytucie Maxa Plancka w Kolonii, instytucji badawczej specjalizującej się w badaniach socjologicznych nad organizacją współczesnych gospodarek. Jednostka ta dysponuje budżetem w wysokości 4,8 miliona euro, zatrudnia ponad 30 etatowych badaczy, oferuje też 27 miejsc dla doktorantów oraz początkujących naukowców ${ }^{2}$. Stanowisko dyrektora daje znaczne możliwości wpływania na profil prac badawczych poprzez wskazywanie priorytetowych obszarów dociekań i określanie tematyki prac doktorskich. Rozważania Beckerta zawarte w Imagined Futures można zatem traktować jako wskazówkę dotyczącą tego, jakie badania będą w przyszłości podejmowane w Instytucie, a nawet jako próbę wpłynięcia na kierunek rozwoju całej subdyscypliny, jaka jest nowa socjologia gospodarki. Naukową reputację Beckerta potwierdziło przyznanie mu w 2018 roku przez Niemiecką Wspólnotę Badawczą nagrody imienia Leibniza - jednego z najważniejszych wyróżnień naukowych w Niemczech, które jedynie wyjątkowo trafia w ręce badaczy społecznych i humanistów. Wreszcie, Imagined Futures ukazała się w prestiżowym wydawnictwie Harvard University Press, co zapewniło publikacji odpowiednią zauważalność. Można powiedzieć, że rozgłos wokół Imagined Futures zarówno świadczy o instytucjonalnej sile nauki niemieckiej, jak i potwierdza wysoką pozycję jej autora w dziedzinie współczesnej teorii społecznej.

Istnieją też poważne racje merytoryczne stojące za uznaniem, z jakim spotkała się Imagined Futures. Przynajmniej od czasu ostatniego kryzysu finansowego coraz częściej kwestionuje się zdolność ekonomii - w szczególności zaś jej głównego nurtu wyrastającego z tradycji neoklasycznej - do adekwatnego wyjaśniania zjawisk gospodarczych. Sytuacja ta sprawia, że

${ }^{2}$ Informacje te podaję za stroną internetową Instytutu Maxa Plancka: www.mpifg.de, dostęp: 02.08.2018. 
publiczność chętnie zwraca się w stronę podejść alternatywnych. Jednocześnie rozwój badań empirycznych w obrębie nowej socjologii ekonomicznej - a także w ramach pokrewnych ujęć, takich jak instytucjonalna ekonomia polityczna, studia nad nauką i technologia, antropologia gospodarcza czy ekonomia heterodoksyjna - sprawił, że możliwe stało się przedstawienie całościowej interpretacji współczesnej gospodarki w oparciu o ustalenia tych dyscyplin. Praca Imagined Futures może być czytana jako autorskie podsumowanie tego, co współczesna socjologia i humanistyka mają nam do powiedzenia na temat takich kluczowych dla zrozumienia gospodarki kategorii, jak kredyt, pieniądz, innowacje, inwestycje czy konsumpcja. Ponadto, przyczyn popularności omawianej książki należy szukać w - nomen omen - wyobrażonej przyszłości, tym razem dotyczącej nauk społecznych. Wiele badań w zakresie ekonomii politycznej w ostatnich latach przyjmowało perspektywę historycznego instytucjonalizmu, podkreślającego zależność od ścieżki i determinującą rolę przeszłości w wyjaśnianiu ewolucji systemów gospodarczych. Nie negując wagi tych ustaleń, w Imagined Futures Jens Beckert proponuje, abyśmy przyjrzeli się bliżej roli, jaką w gospodarce odgrywa przyszłość - a w szczególności oczekiwania głównych aktorów życia społecznego oraz różne dyskursywnie konstruowane narracje i wyobrażenia na temat tego, co dopiero ma nadejść. Bez zrozumienia roli konstruowanych społecznie oczekiwań i wyobrażeń na temat przyszłości - i to jest główna teza Jensa Beckerta - nie sposób bowiem zrozumieć dynamiki kapitalizmu. Jeżeli badacze i badaczki dadzą się uwieść narracji Beckerta, to obrazy przyszłości staną się jednym z głównych przedmiotów dociekań w naukach społecznych, w szczególności zaś w ekonomii politycznej i socjologicznej refleksji nad gospodarką.

W dalszej części tego eseju postaram się przedstawić konsekwencje Beckertowskiej tezy, że przyszłość ma znaczenie (future matters) dla trzech grup zagadnień: (1) krytyki aparatu poznawczego ekonomii głównego nurtu; (2) programu badawczego socjologii gospodarki i ekonomii politycznej; (3) rozumienia dynamiki oraz istoty kapitalizmu.

\section{/// W krainie iluzji: ekonomia głównego nurtu}

Jens Beckert buduje swój wywód wokół rozróżnienia na ryzyko i niepewność, które wprowadził amerykański ekonomista Frank Knight. Za ryzykowne możemy uznać te sytuacje, dla których możliwe jest oszacowanie prawdopodobieństwa wystapienia określonych zdarzeń. Ryzyko jest zatem co do zasady poznawalne i daje się zmierzyć przy pomocy odpowiednich 
metod statystycznych. Z kolei przez niepewność Beckert rozumie za Knightem takie sytuacje, w których „nie ma możliwości sformułowania w żaden sposób grupy przypadków wystarczająco jednorodnych, aby umożliwić ilościowe określenie rzeczywistego prawdopodobieństwa" (Beckert 2016: 42). Innymi słowy, niepewność jest zasadniczo niepoznawalna, a próby jej szacowania przy pomocy rachunku prawdopodobieństwa muszą zakończyć się porażką. Sytuacje, z którymi mamy do czynienia w życiu społecznym, można podzielić na ryzykowne i niepewne. Podział ten nie jest co prawda ściśle rozłączny, gdyż możliwe do wyobrażenia są sytuacje pośrednie, zawierające w sobie zarówno element ryzyka, jak i pierwiastek niepewności. Tym niemniej Jens Beckert uważa, że dla zrozumienia dynamiki gospodarki kapitalistycznej kluczowe znaczenie maja wybory podejmowane w obliczu niepewności. Chociaż kategoria niepewności odgrywała ważną rolę w twórczości takich ekonomistów, jak John Maynard Keynes czy wspomniany już Frank Knight, to nie było dla niej miejsca w doskonale przewidywalnym - czy też, jak moglibyśmy powiedzieć za Paulem Samuelsonem: ergodycznym - światopoglądzie ekonomii neoklasycznej (Samuelson 1968, Davidson 2010) $)^{3}$. Wraz z nastaniem hegemonii podejścia neoklasycznego myślenie ekonomiczne zostało zdominowane przez iluzoryczne przeświadczenie, że przyszłość gospodarcza jest zasadniczo przewidywalna.

Zdaniem Beckerta teorie tworzone w ramach ekonomii głównego nurtu - to znaczy ekonomii neoklasycznej wraz z jej rozlicznymi modyfikacjami i kontynuacjami - są serią nieudanych prób zredukowania niepewności do rangi dającego się skalkulować ryzyka. Przykładowo, teoria równowagi ogólnej opiera się na założeniu, że uczestnicy wymiany rynkowej dysponują doskonałą informacją, w tym również pełnią wiedzy na temat przyszłości. Innymi słowy, teoria ta zakłada, że istnieje znana z góry „cena dla parasolek dostarczanych podczas deszczu w Paryżu 18 maja 2064 roku”

\footnotetext{
${ }^{3}$ Pojęcie ergodyczności pojawia się na marginesie prac Paula Samuelsona, w których sugerował on, że przekonanie o ergodycznym charakterze systemu gospodarczego jest kluczowym, choć nie zawsze otwarcie wysławianym założeniem leżącym u podstaw ekonomii neoklasycznej. Współczesna kariera kategorii ergodyczności związana jest z przechwyceniem tego pojęcia przez krytyków ekonomii neoklasycznej, takich jak Paul Davidson, którzy uznali je za charakterystyczne dla sposobu konceptualizacji świata w teoriach głównego nurtu. Hipoteza ergodyczności została zaczerpnięta z mechaniki statystycznej. Głosi ona, że ,istnieje unikalne equilibrium w długim okresie czasu, które jest niezależne od warunków początkowych” (Samuelson 1969: 184). W myśl tej koncepcji ekonomia przypomina zatem bardziej fizykę niż historię. Co więcej, ergodyczny pogląd na świat zakłada też, że przyszłość jest z góry określona i daje się opisać za pomocą odpowiedniej funkcji prawdopodobieństwa (Beckert 2016: 45). Według Paula Davidsona w świecie ergodycznym przyszłość jest ,jedynie statystycznym cieniem przeszłości” (Davidson 2010: 17). Przyjęcie takiego poglądu opiera sią na założeniu, że główne parametry systemu gospodarczego nie podlegają zmianom w czasie. Odrzucenie hipotezy ergodyczności charakteryzuje współczesną ekonomię post-keynesowską (Bludnik 2014).
} 
(Beckert 2016: 38) ${ }^{4}$. Inaczej z problemem niepewności radzi sobie teoria racjonalnych oczekiwań, która przyjmuje, że rzeczywistość gospodarcza ma charakter procesu stochastycznego, w ramach którego możemy oszacować prawdopodobieństwo zaistnienia określonych zdarzeń. Przyszłość jest więc zasadniczo powtórzeniem kombinacji znanych z przeszłości. W konsekwencji mamy prawo założyć, że aktorzy ekonomiczni zachowują się racjonalnie, opierając swoje działania na najbardziej prawdopodobnych przewidywaniach, a przyszłość nigdy nie jest dla nich zasadniczym zaskoczeniem. Innym przykładem marginalizowania roli niepewności jest hipoteza efektywnego rynku sformułowana przez Eugena Famę, zgodnie z którą wyceny aktywów przez rynek finansowy odzwierciedlają wszystkie posiadane informacje. W myśl tej koncepcji na rynkach finansowych nie powinny występować takie zjawiska, jak bańki spekulacyjne, kryzysy finansowe czy transakcje typu insider trading, które zakładają istnienie poważnej rozbieżności między rynkową a rzeczywistą wartością określonych papierów wartościowych.

Teorie rozwijane w ramach ekonomii głównego nurtu zawodza podwójnie. Po pierwsze, sprowadzając niepewność do roli skalkulowanego ryzyka, nie potrafią wyjaśnić dynamicznej natury kapitalizmu. Koncepcje zakładające efektywność rynków i racjonalność aktorów działań gospodarczych nie dysponuja adekwatnym wyjaśnieniem dla baniek spekulacyjnych i kryzysów gospodarczych. Co więcej, gdyby przyszłość była z góry znana, a efekty działań ekonomicznych możliwe do przewidzenia, nie byłoby wiele miejsca dla zjawiska, które Joseph Schumpeter określił mianem twórczej destrukcji polegającej na rewolucyjnej zmianie dominujących metod produkcji. Ponadprzeciętnie wysokie zyski z inwestycji oraz napędzające wzrost gospodarczy innowacje możliwe są bowiem jedynie w warunkach zasadniczej niepewności co do przyszłych rezultatów podejmowanych działań.

Być może bardziej interesująca porażka ekonomii głównego nurtu jest związana z tym, że nie potrafi ona w sposób adekwatny zrozumieć samej siebie. Ekonomia jest bodaj jedyną nauką społeczną, która w dalszym ciąu mówi o prawach - prawie popytu i podaży, prawie Saya, prawie jednej ceny etc. Tego rodzaju język jest jednak mylący, gdyż sugeruje, że - w sytuacji, gdy znane są określone warunki wyjściowe, a inne czynniki nie ulegaja

\footnotetext{
${ }^{4}$ Przykład z parasolkami Becekrt zaczerpnął zapewne z popularnego artykułu Franka Hahna, jednego z twórców nowoczesnej teorii równowagi (Hahn 1980: 124). Fakt, że nie znamy przyszłej ceny parasolek, jest teoretycznie doniosły, gdyż w sytuacji braku cen na przyszłe dobra i towary neoklasyczne założenie o maksymalizacji zysku (lub użyteczności) traci rację bytu (Hahn 1980: 134).
} 
zmianie - można przewidzieć przyszłe procesy i zjawiska gospodarcze. Po drugiej wojnie światowej dużo energii i środków zainwestowano w rozwój makroekonomii i badań nad przebiegiem cykli koniunkturalnych, które miały pozwolić z wyprzedzeniem przewidywać recesje. W tym celu budowano zaawansowane modele ekonometryczne mające generować coraz dokładniejsze przewidywania. Z perspektywy czasu jasne jest, że wysiłki te zakończyły się niepowodzeniem. Ekonomiści, podobnie jak inni badacze społeczni, nie potrafili przewidzieć epokowych wydarzeń historycznych, takich jak upadek systemu komunistycznego czy kryzys ekonomiczny roku 2017. Z kolei bieżące prognozy przebiegu koniunktury zakładają zbyt duży margines błędu statystycznego, aby mogły być użyteczne. Retrospektywna analiza raportów niemieckich ośrodków analitycznych pokazuje, że nawet pomimo tych metodologicznych zastrzeżeń rzeczywisty wzrost gospodarczy odbiegal istotnie od formułowanych prognoz (Beckert 2016: 224). W tej sytuacji uzasadniona wydaje się konstatacja, że „skoro świat społeczny nie daje się przewidywać, to być może badacze społeczni powinni powstrzymać się przed przewidywaniem" (tamże: 243), a w każdym razie nie powinni oni twierdzić, że ich przepowiednie maja stricte naukowy charakter.

Niekiedy próbuje się uniknąć tych pesymistycznych konkluzji, wskazując postępy, jakie rzekomo dokonały się ostatnio w zakresie metodologii i ekonometrii, czy odwołując się do przykładu maverickón, takich jak Nouriel Roubini czy Steve Keen, którzy utrzymują, że przewidzieli ostatni kryzys ekonomiczny. Kontrargumenty te nie sa jednak przekonujące. Sceptycyzm wobec prognoz nie opiera się przecież na twierdzeniu, że przewidywania są zawsze błędne, ale na tezie, że w naukach społecznych nie występuje zjawisko kumulatywnego wzrostu zdolności do przewidywania i kontroli (Hesse 1980: 193). Można zaryzykować tezę, że możliwości predykcyjne ekonomii nie zwiększyły się istotnie od czasów Adama Smitha. Niewiele też wskazuje na to, aby przewidywania oparte na modelach ekonometrycznych przewyższały domysły formułowane przez nieprofesjonalnych uczestników życia społecznego. Jens Beckert ma więc rację, kiedy sugeruje, że pod względem trafności prognozy ekonomiczne nie są wiele lepsze od przepowiedni wyroczni delfickiej czy horoskopów stawianych przez telewizyjnego wróżbitę Macieja. Jeżeli ekonomia różni się czymś od magii, to różnica ta nie polega na większej „naukowości” jej przewidywań, ale na roli, jaką prognozy makroekonomiczne odgrywają w koordynowaniu współczesnych gospodarek. Regularnie publikowane raporty makroekonomiczne służą ujednoliceniu wiedzy na temat procesów gospodarczych i oczekiwań dotyczących ich 
przyszłego przebiegu wśród decydentów sektora prywatnego i publicznego. Jak przekonuje Beckert, rzeczywistą funkcją prognoz nie jest więc przewidywanie przyszłości, ale ułatwianie wzajemnej komunikacji między elitami polityki i biznesu. Ekonomia jest dostarczycielką fikcyjnych wyobrażeń na temat przyszłości, ale przynajmniej niektóre z nich mamy prawo uznać za pożyteczne dla stabilizacji współczesnych gospodarek.

\section{/// Przyszłość i zwrot hermeneutyczny w ekonomii politycznej}

Odkrycie wyobrażonej przyszłości jako koniecznego horyzontu działań gospodarczych ma fundamentalne znaczenie dla sposobu uprawiania ekonomii politycznej. We wstępie do swojej pracy Beckert przekonuje, że jego celem jest „doprowadzenie do ściślejszego dialogu między socjologia gospodarki a ekonomia polityczna”" (Beckert 2016: 7). Według Beckerta stosunek nowej socjologii gospodarczej do instytucjonalnej ekonomii politycznej (rozwijanej głównie w ramach politologii) byłby analogiczny do relacji między mikroekonomia a makroekonomią. Innymi słowy, socjologia gospodarki dostarczać ma mikrofundamentów dla instytucjonalnej analizy funkcjonowania kapitalizmu w makroskali. W celu wyjaśniania behawioralnych aspektów kapitalistycznej dynamiki Beckert wprowadza kategorię fikcyjnych oczekiwań. Pojęcie to jest przeciwstawne wobec ekonomicznej koncepcji racjonalnych oczekiwań. Jak widzieliśmy, teoria racjonalnych oczekiwań zakładała, że aktorzy w swoich przewidywaniach posługują się szacunkami prawdopodobieństwa. Jeśli jednak rzeczywistość ekonomiczna nie ma charakteru ergodycznego, a niepewność nie daje się zredukować to ryzyka, to oczekiwania dotyczące przyszłości nie mogą być racjonalne w znaczeniu postulowanym przez ekonomię głównego nurtu. W warunkach niepewności oczekiwania maja zawsze fikcyjny charakter przynajmniej w tym sensie, że nie mogą być zweryfikowane przy wykorzystaniu dostępnych danych statystycznych.

Kwestionując ekonomiczną teorię racjonalnych oczekiwań, Beckert nie sugeruje bynajmniej, że oczekiwania dotyczące przyszłości są całkowicie przypadkowe. Gdyby tak było, koordynacja działań aktorów gospodarczych byłaby zapewne niemożliwa. Beckert podkreśla trzy cechy fikcyjnych oczekiwań, które sprawiają, że mogą one skutecznie redukować niepewność związaną z przyszłością, a przez to przyczyniać się do koordynacji współczesnych gospodarek. Po pierwsze, oczekiwania aktorów gospodarczych sa konstruowane społecznie. Wyobrażenia na temat przyszłości są wytworem procesów społecznych, których nie da się sprowadzić 
do idiosynkratycznego osądu poszczególnych jednostek. Zależą one od takich czynników, jak zestaw możliwości wynikający z zajmowanej pozycji w strukturze klasowej, sieci osobistych znajomości, obowiązujące w danej społeczności ramy kulturowe (np. wizje dobrego życia), wyobrażenia rozpowszechniane przez media masowe czy utopie oferujące wizje lepszego życia. Po drugie, fikcyjne oczekiwania często przybierają formę opowieści na temat przyszłości. Pod tym względem przypominają one fikcję literacką. Narracje moga wykreować pewne wyobrażenia przyszłości, które aktorzy życia gospodarczego traktuja jako rekwizyty służące podejmowaniu decyzji. Inwestorzy zachowuja się tak, jakby wierzyli w plany rozwoju firmy; banki udzielają kredytów pod wpływem opowieści odwołujących się do skutecznych przykładów restrukturyzacji. Rzecz jasna, wiara ta często się załamuje, czego przejawem są takie zjawiska, jak bankructwa i kryzysy gospodarcze. Tym niemniej, bez pomocy narracji trudno byłoby rozproszyć wątpliwości towarzyszące podejmowaniu decyzji. Po trzecie wreszcie, fikcyjne oczekiwania są naznaczone relacjami władzy. Zdaniem Beckerta gospodarka kapitalistyczna jest polem ciagłych zmagań o to, które wyobrażenia na temat przyszłości i czyje oczekiwania ostatecznie wezmą górę. Można więc mówić o polityce oczekiwań rozumianej jako zestaw świadomych strategii retorycznych podejmowanych przez aktorów życia gospodarczego i zmierzających do narzucenia własnej narracji na temat przyszłości.

Pracę Beckerta można czytać jako argument na rzecz ściślejszego aliansu między hermeneutyką a ekonomia polityczną. „Znaczenie i interpretacja - przekonuje Beckert - są kluczowe dla rygorystycznego badania decyzji ekonomicznych i ich rezultatów" (Beckert 2016: 274). Aktorzy działają bowiem w oparciu o znaczenia, jakie nadaja zjawiskom ekonomicznym. Sytuacje, z którymi konfrontowani są uczestnicy życia gospodarczego, stają się zrozumiałe w wyniku komunikacyjnych procesów nadawania i kontestowania znaczenia. $Z$ tego względu „działanie ekonomiczne musi być rozumiane jako zakotwiczone w narracyjnych konstrukcjach, co implikuje, że żadne empiryczne badania nad gospodarką nie mogą oderwać się od dociekań z zakresu hermeneutyki działania ekonomicznego" (Beckert 2016: 274). Podkreślanie interpretacyjnego wymiaru dociekań prowadzonych w obrębie socjologii gospodarki i ekonomii politycznej ściśle wiąże się z tym, co za Karlem Polanyim zwykliśmy określać mianem społecznego zakorzenienia gospodarki (Polanyi 2010). W programowym artykule Beckert wskazuje, że praktyczną odpowiedzią na niepewność cechująca życie gospodarcze w nowoczesnych społeczeństwach rynkowych jest próba ograniczenia zakresu możliwych wyborów przysługujących aktorom życia go- 
spodarczego (Beckert 1999: 819). Taką funkcję pełnią rozmaite urządzenia społeczne, takie jak nawyki, tradycje, normy, instytucje czy relacje władzy, które redukują liczbę społecznie akceptowalnych interpretacji rzeczywistości oraz dopuszczalnych sposobów działania. Społeczne zakorzenienie gospodarki jest zatem sposobem na minimalizowanie zjawiska niepewności charakterystycznego dla współczesnych złożonych społeczeństw.

Ze wszystkich nauk społecznych ekonomia bodaj w najmniejszym stopniu okazała się podatna na konsekwencję zwrotu językowego, który miał miejsce we współczesnej filozofii i humanistyce. Tym niemniej, jeżeli podnoszone przez Beckerta argumenty są trafne - a sądzę, że są - to współczesnego życia gospodarczego nie da się pojąć bez hermeneutyki rozumianej szeroko jako odkrywanie znaczenia towarzyszącego działaniom aktorów życia gospodarczego. Jednocześnie takie kategorie jak symbole, interpretacje i znaczenia nie dają się łatwo wpasować w matematyczne instrumentarium współczesnej ekonomii, a typowy program kształcenia na kierunkach ekonomicznych nie stwarza wielu okazji do pracy z tekstem oraz rozwijania wrażliwości hermeneutycznej. Z tej racji można się spodziewać, że analizy wychodzące naprzeciw formułowanym przez Beckerta postulatom będą raczej dziełem antropologów, socjolożek i adeptów nauk politycznych niż badaczy i badaczek reprezentujących ekonomię głównego nurtu.

\section{/// Poza żelazną klatką racjonalności}

Powstanie kapitalizmu często bywa interpretowane jako zmiana kulturowa zwiastująca zmierzch tradycyjnych form życia społecznego. W myśl popularnej interpretacji wraz z triumfem gospodarki kapitalistycznej zostaliśmy zamknięci w Weberowskiej żelaznej klatce racjonalności, a nasze życie społeczne zostało podporządkowane wymogom rozumu instrumentalnego sprowadzającego myślenie do chłodnej kalkulacji środków i celów. Upowszechnieniu się zasad profesjonalnej księgowości i rozrostowi nowoczesnej biurokracji towarzyszyć miał upadek tradycyjnych wyobrażeń mających swoje źródło w religii i magii. W ten sposób świat nowoczesny został ostatecznie odczarowany. Jens Beckert odrzuca ten pogląd. Wszechobecność zjawiska niepewności oznacza, że całkowita racjonalizacja życia społecznego nie jest możliwa. Nawet gdyby aktorzy chcieli kierować się racjonalnym rachunkiem środków i celów, brak wiarygodnej wiedzy na temat przeszłości uniemożliwia dokonanie takich kalkulacji (Beckert 1999: 819). Kapitalizm jawi się niemieckiemu socjologowi jako porządek społecz- 
ny oparty na kolektywnie podzielanych wyobrażeniach i rytuałach, które nie różnią się co do istoty od wierzeń religijnych i obrzędów magicznych występujących w społeczeństwach przednowoczesnych. Postaram się zilustrować ten pogląd na przykładzie argumentów Beckerta odnoszących się do takich filarów systemu kapitalistycznego, jak pieniądz, kredyt, inwestycje i konsumpcja.

W sytuacji fundamentalnej niepewności dotyczącej przyszłości kapitalizm z konieczności musi opierać się na wierze. Zjawisko to jest najbardziej widoczne w sferze relacji pieniężnych. Beckert $\mathrm{z}$ aprobata przytacza opinię Andre Orelana, francuskiego ekonomisty związanego ze szkoła konwencji, że kapitalizm jest systemem opartym na fascynacji pieniędzmi i obsesyjnemu dążeniu do ich gromadzenia (Beckert 2016: 109). Podążając za myślą Émile’a Durkheima, Beckert argumentuje, że pieniądz jest współczesnym totemem - reprezentuje on władzę, jaką społeczeństwo ma nad dążeniami i pragnieniami jednostek. Aby pieniądz mógł pełnić swoją podstawową funkcję nośnika wartości, musimy przyjąć, że jego wartość będzie taka sama w przyszłości. Wiara w stabilność waluty, podobnie jak każdy inny rodzaj zinstytucjonalizowanej religii, potrzebuje oddanych kapłanów. W kapitalizmie taką rolę odgrywają przede wszystkim banki centralne, których szefowie regularnie publikują komunikaty i wygłaszaja przemówienia mające przekonać uczestników gry rynkowej, że pieniądz nie straci swojej wartości. Fikcja niezmiennej wartości pieniądza, by posłużyć się trafnym określeniem Philipa Mirowskiego, jest zatem utrzymywana za pomoca wyrafinowanych strategii retorycznych realizowanych przez polityków i przedstawicieli instytucji finansowych (Beckert 2016: 107). Co więcej, kapitalizm wedle Schumpeterowskiej definicji przytaczanej przez Jensa Beckerta jest systemem opartym na zadłużeniu. Zarówno kredyty, jak i inwestycje oparte są na wierze w to, że wzrost gospodarczy w przyszłości zrekompensuje poniesione dzisiaj wyrzeczenia. Nie przypadkiem słowo kredyt, podobnie jak wyraz credo, pochodzą od łacińskiego czasownika credere - „wierzyć”. Wiara w spłatę kredytów nie może być jednak brana za pewnik, a podtrzymanie optymizmu kredytodawców i inwestorów wymaga ciagle ponawianych perswazyjnych wysiłków przyjmujących formę narracji na temat oszałamiających możliwości zarabiania pieniędzy w przyszłości.

Również inwestycje, kolejny z instytucjonalnych filarów systemu kapitalistycznego, nie maja ściśle racjonalnego charakteru. Inwestycje można podzielić na trzy rodzaje. Po pierwsze, pracownicy inwestują w „kapitał ludzki”, wierząc, że nabyta wiedza i umiejętności pozwolą im zdobyć bar- 
dziej stabilną i lepiej płatną pracę. Rozwojowi kapitalistycznych stosunków społecznych towarzyszyła eksplozja formalnej edukacji. Według danych przytaczanych przez Jensa Beckerta w 1900 roku jedynie 6,5\% Amerykanów miało wykształcenie średnie, podczas gdy w 1980 roku ten sam współczynnik wynosił już 80\% (Beckert 2016: 159). Po drugie, kapitaliści inwestuja w kapitał trwały (to jest fabryki i środki produkcji) w nadziei, że przyszłe zyski z produkcji zrekompensują bieżące wyrzeczenia. Chociaż inwestorzy moga niekiedy ubezpieczyć się od określonego ryzyka (np. ryzyka walutowego), to jednak próba ubezpieczenia się od wszelkich nieplanowanych zdarzeń pozbawiłaby inwestycje rentowności. Po trzecie, na rynkach finansowych mają miejsce inwestycje spekulacyjne oparte na próbach odgadnięcia zachowania innych uczestników rynku. Inwestycje - w każdej z trzech podstawowych odmian - zależą od fikcyjnych oczekiwań na temat przyszłości, które sa rozpowszechniane w formie uwodzicielskich opowieści. Przyszłych pracowników należy przekonać, że zdobyte wykształcenie pozwoli im spełnić sen o lepszym życiu lub zrealizować wymarzony scenariusz kariery. Kapitaliści inwestujący w środki produkcji kuszeni sa technologicznymi utopiami zapewniającymi, że przyszłość należy właśnie do tych technologii, które wkrótce staną się ich własnością. Uczestnicy rynków finansowych kierują się zbiorowymi konwencjami dotyczącymi wartości określonych papierów wartościowych oraz przyjmują definicje sytuacji rynkowej kreowane przez profesjonalnych analityków. Dla każdego typu inwestycji konstruowane są rozmaite rankingi, które mają przekonać nas, że dany kierunek studiów, typ technologii czy określona klasa papierów wartościowych gwarantuje najwyższa stopę zwrotu w przyszłości. Utrata wiary w moc opowieści prowadzi do spadku stopy inwestycji, co w realiach kapitalizmu oznacza spowolnienie tempa wzrostu, a nawet recesję. Uwodzicielskie historie trzeba zatem opowiadać wciąż na nowo, ufając, że przynajmniej na chwilę zdołaja one rozproszyć uzasadnione wattpliwości uczestników życia gospodarczego.

Obszarem, w którym irracjonalny charakter kapitalizmu manifestuje się w pełni, jest sfera konsumpcji. Świat konsumpcji może być przykładem na trafność tezy Durkheima, który dowodził, że w epoce nowoczesnej dokonuje się zjawisko migracji sacrum ze sfery religijnej do obszarów życia tradycyjnie uznawanych za świeckie. Jak wskazywał już John Maynard Keynes, w gospodarce kapitalistycznej popyt na towary i usługi nie jest automatycznie gwarantowany. $Z$ tego względu musi być on stale podtrzymywany przez narracje - produkowane głównie przez przemysł reklamowy - nadające symboliczną wartość towarom sprzedawanym na rynku. 
Beckert rozróżnia wartość fizyczna - to, co dany przedmiot „robi” - od wartości symbolicznej, opartej na wyobrażonym znaczeniu dóbr. Zdaniem niemieckiego socjologa $\mathrm{w}$ realiach współczesnych gospodarek głównym źródłem wartości dóbr i usług jest symboliczne znaczenie, które im przypisujemy. Idąc dalej, możemy odróżnić wartość pozycyjną, która sygnalizuje status społeczny użytkownika danej rzeczy, od wartości wyobrażeniowej, dotyczącej wyimaginowanych właściwości sprzedawanego przedmiotu. Pod wpływem reklamy przedmioty nabieraja właściwości transcendentalnych - pozwalają ich użytkownikowi przekroczyć bariery związane z czasem, przestrzenią, wartościami czy dystansem społecznym. Przykładowo, kupując wino z czasów Napoleona, możemy sobie wyobrazić, że stajemy się niejako uczestnikami historycznych zmagań. Natomiast stosując szampon do włosów reklamowany przez znanego piłkarza, możemy mieć poczucie przekroczenia granic oddzielających zwykłych ludzi od celebrytów. Konsumpcja, zdaniem Beckerta, nie ma indywidualistycznego czy stricte hedonistycznego charakteru. Konsumując dobra i usługi, potwierdzamy symbolicznie naszą przynależność do określonej wspólnoty. Przykładowo, uczestnicy zlotu posiadaczy starych samochodów biorą udział w quasi-religijnym rytuale, w trakcie którego zbiorowo celebrują unikatową wartość swoich aut. Pod pewnym względem konsumpcja odbiega jednak od religii. Konsumenci doznaja rozczarowania nabytymi przedmiotami dużo szybciej i dużo częściej, niż ma to miejsce w przypadku tradycyjnego kultu religijnego. Funkcjonowanie kapitalizmu oparte jest zatem na ciagle ponawianym cyklu nabywania i utraty wartości przez wymieniane na rynkach dobra i usługi.

Jaki jest stosunek Jensa Beckerta do zaczarowanego świata kapitalizmu? Mieszankę kreatywności i destrukcyjności, która charakteryzuje kapitalizm, Jens Beckert jest gotowy określić - podążając śladami teologa Paula Tillicha - jako demoniczna (Beckert 2016: 285). Kapitalizm musi cały czas zmieniać swoje historyczne formy, co do zasady jednak pozostaje on niezmieniony. Nieustające rewolucjonizowanie sposobów produkcji i form życia społecznego nie prowadzi do zmiany zasadniczej struktury systemu podporządkowanego niekończącej się akumulacji kapitału. „Wyobrażone przyszłości kapitalizmu - wyrokuje Beckert - odzwierciedlają niekończące się dążenie do odnowy kapitalistycznej zasady zysku" (tamże: 285). Pomimo marksistowskiego języka trudno byłoby uznać niemieckiego socjologa za rewolucjonistę nawołującego do obalenia systemu kapitalistycznego. Po lekturze Imagined Futures jesteśmy raczej skłonni spoglądać na kreowane w kapitalizmie obrazy świetlanej przyszłości z większą dozą sceptycyzmu 
i podejrzliwości. Za zagrożenie dla kapitalizmu przywykliśmy uznawać utopijne wizje postkapitalistycznej przyszłości w rodzaju tych, jakie głosili niegdyś komuniści czy rewolucjoniści wywodzący się z Nowej Lewicy. Jednak, jak przypomina Beckert, przykład kultury hipisowskiej oraz dzieje radykalnych ruchów lat 60 . pokazują, że wizje niekapitalistycznej przyszłości nader łatwo zamienić w towar. Lektura pracy Jensa Beckerta nasuwa przypuszczenie, że prawdziwym zagrożeniem dla kapitalizmu może okazać się niewiara w lepsza przyszłość. Jak się wydaje, ten rodzaj sceptycyzmu wobec składanych w systemie kapitalistycznym obietnic staje się postawą coraz bardziej powszechną. Świadczyć o tym mogą utyskiwania na millenialsów, niechcących rzekomo uczestniczyć w kapitalistycznej kulturze pracy, zyskujące na popularności ruchy antykonsumpcjonistyczne czy rosnąca popularność idei ekologicznych wśród niektórych segmentów klasy średniej. Poza zakresem swoich rozważań Beckert pozostawił frapujące pytanie, czy pesymizm odnośnie do przyszłości może zyskać kiedyś polityczny wyraz i jak taka oparta na utracie złudzeń polityka mogłaby wyglądać w praktyce.

Bibliografia:

/// Beckert J., Bronk R., red. 2018. Uncertain Futures. Imaginaries, Narratives and Calculation in the Economy, Oxford University Press.

/// Beckert J. 2016. Imagined Futures. Fictional Expectations and Capitalist Dynamics, Harvard University Press.

/// Beckert J. 1996. What is Sociological About Economic Sociology? Uncertainty and Embeddedness of Economic Action, „Theory and Society”, vol. 25, No 6, s. $803-840$.

/// Bludnik I. 2014. Ergodyczność i nieergodyczność otoczenia gospodarczego a rola państwa, „Studia Ekonomiczne”, nr 180, cz. 1, s. 11-22.

/// Campbell J.L. 2017. Review, „American Journal of Sociology”, vol. 122, Issue 5, s. 1575- 1577.

/// Davidson P. 2010. Risk and Uncertainty, [w:] The Economic Crisis and the State of Economics, red. R. Skidelsky, Ch. W. Wigström, Palgrave Macmillan, s. 13- 29 . 
/// DiMaggio P. 2018. Our Faith-Based Economy, „Distinktion: Journal of Social Theory", s. 1- 8 .

/// Gonzalez F., Serafin M. 2017. Uncertainty and the Social Order of the Economy: Introduction to the Economic Sociology of Jens Beckert, „Studia Socjologiczne”, nr 3(226), s. 239- 256.

/// Hahn F. 1980. General Equilibrium Theory, „The Public Interest”, No 36, s. $123-138$.

/// Harrington B. 2016. Capitalist's Imagination, https://www.theatlantic. com/business/archive/2016/07/the-capitalists-imagination/491009/, dostęp: 02.08.2018.

/// Jackson G. 2017. A Future for Capitalism, „European Journal of Sociology", vol. 58, Issue 3, s. 460- 467.

/// Polanyi K. 2010. Wielka transformacja. Polityczne i ekonomiczne znaczenie naszych crasów, tłum. M. Zawadzka, PWN./// Samuelson P. 1969. Classical and Neoclassical Theory, [w:] Monetary Theory. Selected Readings, red. R.W. Clower, Penguin Books, s. 170- 190.

/// Slocum D. 2016. Book Hotlist: 17 Beach Reads for Creative Leaders This Summer, https://www.forbes.com/sites/ berlinschoolofcreativeleadership/2016/05/15/17-summer-books-creativeleaders-can-read-at-the-beach/\#57c448a1411d, dostęp: 02.08.2018.

/// Maciej Kassner - doktor nauk politycznych, stypendysta Polsko-Amerykańskiej Komisji Fulbrighta, pracownik naukowy Instytutu Filozofii UMK. Obecnie zajmuje się badaniami nad teorią Karla Polanyiego i jej recepcją w obrębie współczesnych nauk społecznych.

Email: maciej.kassner@gmail.com 